ח

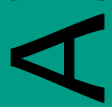

n

Ш

Z

O

$\underline{-}$

$F$

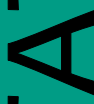

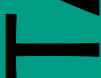

ه

Ш

n

n

$\overline{0}$
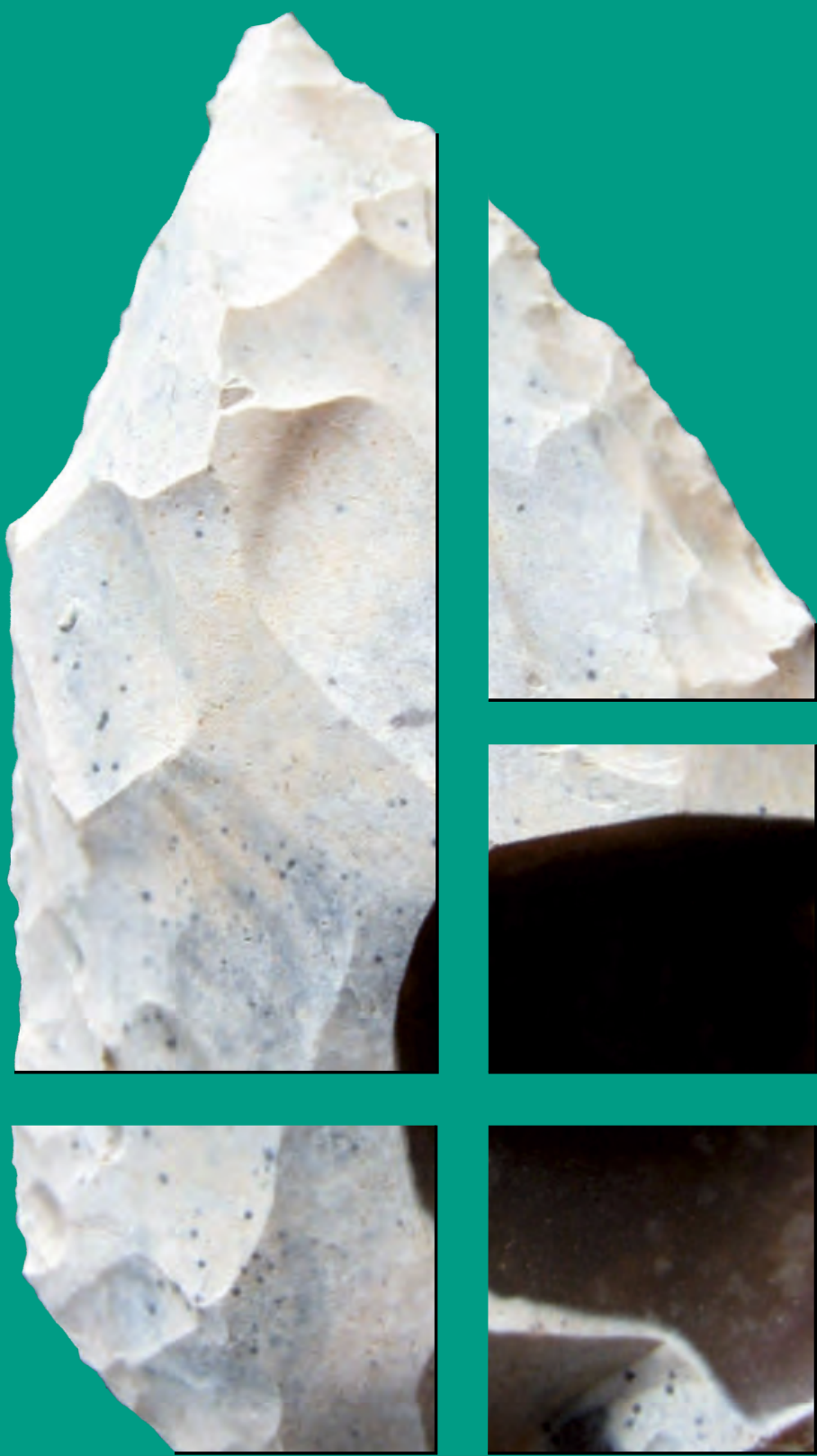

Ser. 3. No.9.| 2021 


\section{Dissertationes Archaeologicae ex Instituto Archaeologico}

Universitatis de Rolando Eötvös nominatae

Ser. 3. No. 9.

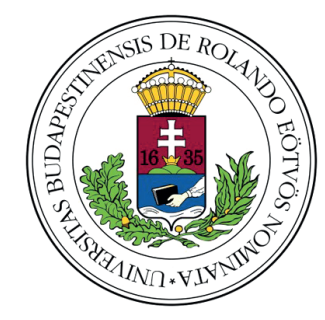

Budapest 2021 


\section{Dissertationes Archaeologicae ex Instituto Archaeologico Universitatis de Rolando Eötvös nominatae}

Ser. 3. No. 9.

Editor-in-chief

Dávid BARTus

Editorial board

László Bartosiewicz (Stockholm University, Stockholm)

Ondřej Chvojкa (University of South Bohemia, České Budějovice)

Zoltán Czajlik (Eötvös Loránd University, Budapest)

Mario Gavranović (Austrian Arhaeological Institute AAS, Vienna)

Hajnalka Herold (University of Exeter, Exeter)

Klára Kuzmová (University of Trnava, Trnava)

Tina Milavec (University of Ljubljana, Ljubljana)

Gábor V. Szabó (Eötvös Loránd University, Budapest)

Tivadar VIDA (Eötvös Loránd University, Budapest)

Technical editor

Gábor VÁcZI

Proofreading

Eszter TímÁr

Strobe DrIVER

Borbála MoHÁcsI

Fruzsina NÉMETH

Eli J. S. WeAVERDYCKE

Aviable online at http://ojs.elte.hu/dissarch

Contact: dissarch@btk.elte.hu

ISSN 2064-4574 (online)

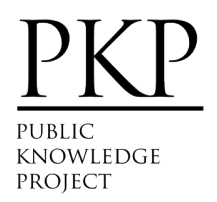

(c ELTE Eötvös Loránd University, Institute of Archaeological Sciences

Layout and cover design: Gábor Váczi

Budapest 2021 


\section{CONTEnTs}

\section{ARTiCles}

Attila PÉNTEK - Norbert FARAgó

Palaeolithic and Mesolithic assemblages from Tunisia

Attila PÉNTEK - Norbert FARAGó

Some remarks on a German chipped stone lithic assemblage of uncertain origin in the collection of the Institue of Archaeological Sciences, Eötvös Loránd University

László Gucsi

Technological observations on a Late Copper Age ceramic assemblage

from Hódmezővásárhely-Kopáncs-Olasz-tanya, Hungary

János Gábor TARBAY

101

A Koszider Period Sword from Tornyospálca-Sírkútgaz (Szabolcs-Szatmár-Bereg County, Hungary)

Ábel GARCZIK

Dolia in the Middle La Tène Period of the Carpathian Basin in the light of new finds from Perkáta-Nyúli-dűlő

Lajos JuHÁsz

An exceptional Sarmatian cast medallion with star and crescent

Gabriella G. DeLBó

New data on the Pannonian glazed casserole handles

Csilla SÁró

The fibula production of Brigetio: Model, semi-finished products, and failed castings

Anita BENES

New data on the capacity of the Roman aqueduct of Brigetio

Melinda SzABó

Status or Role? Differences between the Social Status and Role in Brigetio

Krisztina HoppáL

Roman engraved gems from Southeast Asia 


\section{FiELD REPORTS}

Bence SIMON - Ferenc BARNA

Another barrel-lined well a road section and late Roman graves from Brigetio

Rita RAKONCZAY

Trial excavations in mediaeval churches of Kishartyán, Kisterenye, Mátranovák and Szuha in Nógrád County 2021

\section{Thesis Review Articles}

Tamás KEszi

The change of the pottery style of the Mako and Nagyrév cultures in the Early Bronze Age:

The settlement in Iváncsa-Lapos

Linda Dobosi

Building techniques and building materials in Brigetio:

With the virtual reconstruction of House I/a of the civil town of Brigetio

Csilla SÁRó

Tradition and Romanization by the attire of the Eraviscus tribe 


\title{
New data on the Pannonian glazed casserole handles
}

\author{
Gabriella G. DeLbó \\ Komáromi Klapka György Museum, Komárom \\ delbogabi.kgym@gmail.com
}

Received 21 December 2021 | Accepted 9 January 2022 | Published 2 March 2022

\begin{abstract}
The casseroles with relief decoration handles are one of the typical groups of Pannonian glazed pottery in the $2^{\text {nd }}$ century $\mathrm{AD}$. The 44 relief decorated handles made in clay molds are mostly known from Aquincum, Brigetio, and Mursa, while - up until recently - only two molds have been found in Aquincum and Mursa. The new clay mold with Amor decoration, discovered in Brigetio in 2008, expands our knowledge about the production of early Roman glazed potteries. It is unique that besides this mold, a glazed casserole - made with this specific mold - was also found in Brigetio.
\end{abstract}

Keywords: glazed casserole, casserole handles with relief decoration, roman glazed pottery, Amor

In 2008, a cylindrical clay mold with a semicircular end (Fig 1) ${ }^{1}$ was discovered in the alley east of domus $\mathrm{V}$ in the civil town of Brigetio (Komárom/Szőny-Vásártér) in a layer dated to the second half of the $2^{\text {nd }}$ century $\mathrm{AD}^{2}$ (Figs 2-3). This was used to produce casserole handles with relief decoration and is made of reddish yellow (5YR 6/6) clay. Its maximum height is $8.2 \mathrm{~cm}$, its width is $5 \mathrm{~cm}$, with a thickness of $1.8 \mathrm{~cm}$. It is decorated with a nude figure in the middle, with the characteristic hair knot on top of his head, holding a long staff in his right hand and a jug in the other. It is surrounded by seven irregularly arranged rosettes and a bunch of grapes below. The edges of the handle are adorned by a string of pearls that also surrounds the central motif. The fragment of the potter's name stamp is preserved on the back side of the clay mold: $C \bullet M$. (Fig 1,2).

Four glazed casserole handle fragments are known from Brigetio that had been previously published separately but have never been incorporated together in a single paper.

1. A $3.8 \mathrm{~cm}$ long, $3.9 \mathrm{~cm}$ wide handle with a semicircular ending depicting a female head surrounded by V-shaped leaves. ${ }^{4}$ It found its way to the Kuny Domokos Museum at Tata as part of the Kállay collection. It is made of a light grey material (2.5Y 7/1) with a greenish grey (10Y 7/1) surface covered with an olive-green glaze (5Y 5/4). The decoration is blurred and of lesser quality. A knot of glaze is visible at the tip of the handle (Fig. 5,1).

1 This paper was PRESENTED by the author at the $12^{\text {th }}$ Conference for Young Roman Archaeologists on $4^{\text {th }}$ May 2018, and is based on the chapter "Casserole handles and their molds" from the author's $\mathrm{PhD}$ dissertation on the Pottery production of the settlement complex of Brigetio (Eötvös Loránd University, Budapest 2019, DOI: 10.15476/ELTE.2019.268). I am indebted to Adél Bugán for her advice on the research with the clay mold.

2 Trench J12, SE 145. Among the ceramics there was a Dragendorff (Drag.) 33 terra sigillata cup with the seal of Cinnamus that can be dated to the middle of the $2^{\text {nd }}$ century. The piece was identified by Barbara Hajdu, which I am grateful for.

3 The colors have been determined on the basis of Munsell Soil Color Charts (2009 Year Revised Edition 2015).

4 Inv. nr.: KDM (Kuny Domokos Museum) K1212. BÁnki - Cserményi 1992, 76, Kat. 22, Abb. 45; TopÁL 1993, 245, Nr. 7, 7. kép; TopÁL 1995, 101-102, Nr. 7, Abb. 5.7. 
2. A more elaborately decorated relief fragment in the collection of the Museum of Danube Komárno. ${ }^{5}$ The handle clearly depicts a female bust with her hair parted in the middle and wearing a double bun. She is surrounded by 13 rosettes. According to Verena Gassner, the fragment originates from the area of Brigetio. The $6 \mathrm{~cm}$ long surface is covered by an olive-green glaze ${ }^{6}$ (Fig. 5,2).

3. The third is a handle made from a greyish white material with a greenish yellow glaze. It depicts a naked child running right surrounded by nine circular motifs consisting of rosettes. The fragment is $4.9 \mathrm{~cm} \mathrm{long}$, $4.2 \mathrm{~cm}$ wide, and is in the possession of the Hungarian National Museum (Fig. 5,3).

4. The most important fragment with regards to this paper is the one from the so-called $1^{\text {st }}$ cemetery, located east of the civil town. It was buried in a cremation grave ${ }^{8}$ dated to the $2^{\text {nd }}$ century and is part of the Kállay collection. It is made from a light grey material (2.5Y 7/1) with a pink surface (7.5YR 7/4) covered with an olive-green glaze (5Y 5/6). It is 6.6 long and $4.6 \mathrm{~cm}$ wide. Its relief decoration is identical with the clay mold unearthed in 2008. A nude figure is placed in the center, holding a staff and a jug, surrounded by seven irregularly placed rosettes and a bunch of grapes below (Fig. 6). The string of pearls is not as clearly visible, but one has to take into account that the small motifs shrink during the firing process, and the glaze also blurs the representation's contours. The measurements of the clay mold and the fragment correspond to each other; thus it is reasonable to suppose that the negative was used to prepare this handle.
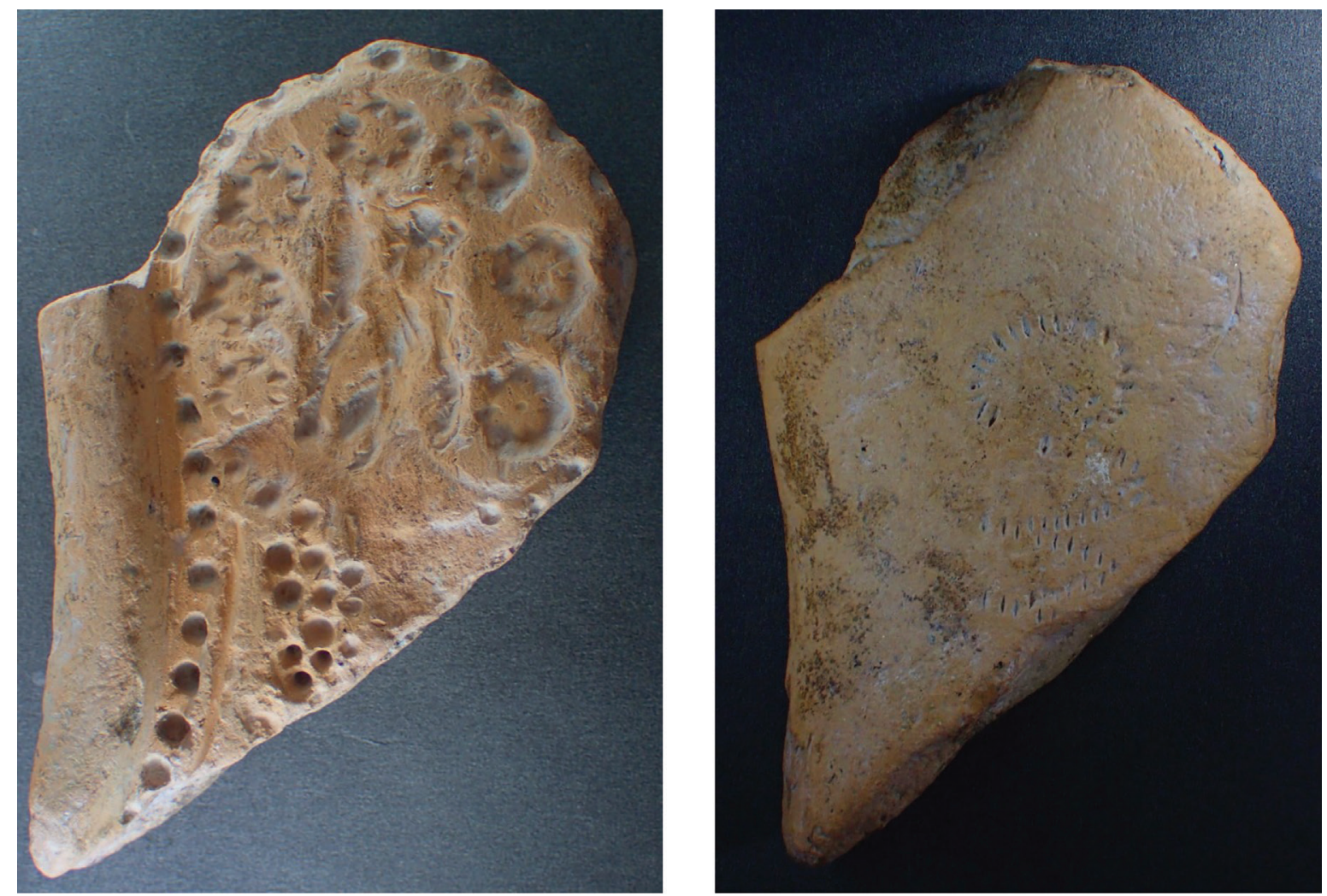

Fig. 1. Clay mold to produce casserole handles from the municipium of Brigetio (Photo by Krisztina Horváth).

KolníK 1984, Abb. 61; Gassner 1991, 18, BR 3, Abb 4.

GASSNER 1991, 18.

7 Inv. nr: HNM (Hungarian National Museum) 78.1983.2, B. BóNIs 1990, 6. kép 2; GASSNER 1991, 16, BR 1, Abb. 4; BÁnki - Cserményi 1992, 76, Kat. 20, Abb. 44; TopÁl 1993, 245-246, Kat. 10, 10. kép; TopÁl 1995, 102, Nr. 10, Abb. 7.10.

8 K712/e. BÁNKi - Cserményi 1992, 76, Kat. 21, Abb. 43; TopÁl 1993, 245, Nr. 9, 9. kép; TopÁl 1995, 101, Nr. Abb. 7.9. The grave goods of grave K712 went to the Kuny Domokos Museum Tata as part of the Kállay collection. According to Kállay's notes, the grave was found in the territory of József Fellner's house. 


\section{The Pannonian glazed casseroles (research history, typology)}

The Pannonian glazed casseroles and relief decorated handles, which follow Gallic metal antecedents ${ }^{9}$, have been in the focus of ceramic studies since the $1990 \mathrm{~s}^{10}$ The vessels typical of the $2^{\text {nd }}$ and early $3^{\text {rd }}$ century $\mathrm{AD}^{11}$ have only been found in small numbers in the province. So far 24 glazed handle fragments have been published from Aquincum, 8 from Mursa, 5 from Sirmium, 4 from Brigetio, and one each from Poetovio, Carnuntum and Arrabona (Fig. 7, App.). ${ }^{12}$ In addition, a complete casserole is known from a grave unearthed in Aquincum ${ }^{13}$ and Arrabona ${ }^{14}$ The fragmentary nature of this material is explained by the fact that they were produced in two pieces, just like their metal antecedents. ${ }^{15}$ The handle was made from the negative mold and was subsequently attached to the wheel turned casserole. The joining part of the two was where the vessel was the most vulnerable and split in two. ${ }^{16}$ Clay mold for producing casserole handles has only been published from Mursa. ${ }^{17}$

The Pannonian handles can be divided into two groups depending on how they end: in a semicircular or an angular/straight form. ${ }^{18}$ The former are more common with 44 extant fragments, while only three of the latter version are known.

The handles with a semicircular ending are framed by rosettes, occasionally a string of pearls (e.g., the fragments and the clay mold from Brigetio). They always show a main motif in the center, a female bust with a double bun, a Gorgoneion or naked child. ${ }^{19}$ The depictions on the handles with straight ends are more complex with several small motifs underneath each other. ${ }^{20}$

\section{The iconography of the glazed casserole handles from Brigetio}

Studies on the subject agree that the function of the glazed casseroles and the relief decoration of the handles are closely connected, and that these were produced to satisfy the buyers' specific needs. ${ }^{21}$ According to Edit B. Thomas, the casserole from Győr served cult purposes: based on its decoration it was connected to the worship of Terra Mater (stylized ram's horns, lyre, krater, feeding bird, ram, and a long-billed bird's head). ${ }^{22}$ Judit Topál dismissed this theory and instead saw it, alongside all the other pieces she examined, as part of the burial ceremony and the cult of the dead, like their metal antecedents. ${ }^{23}$ The representations are also connected to the underworld: ${ }^{24}$ the casserole handle of Arrabona portrays the holy animals of Mercurius, who guides the souls of the dead.

The identification of the female figure with two buns in Cat. 2. is debated. According to Topál, the

9 Rusu-Bolindeb 1997, 326; Popovič 2008, 119. Metal antecedents: TASSINARi 1970; Nuber 1972.

10 GASSNER 1991; TopÁl 1993; TopÁl 1995; BugÁN 2002.

11 BugÁn 2002, 93.

12 Three casserole handle's fragments are known from Moesia (Viminacium, Singidunuum), and also fragments from Noricum.

13 Rikкer et al. 2016, 653, Fig. 3.3.

14 Bínó 1961, 240, 5. kép 4; TopÁL 1993, Kat. 12, 12. kép

15 Rusu-Bolindeb 1997, 326.

16 TopÁL 1993, 247; TopÁL 1995, 103; BugÁN 2002, 106.

17 GASSNER 1991, Abb. 14.

18 TopÁl 1993, 245-246; TopÁl 1995, 101-102; BugÁN 2002, 94.

19 Topál 1993, 245-246, Kat. 1-11, 1-11. kép; Topál 1995, 101-102, Nr. 1-11, Abb. 7.1-11; BugÁn $2002,94$.

20 BugÁN 2002, 94.

21 BugÁN 2002, 106.

22 Thomas 1961, notes 24, 33.

23 TopÁl 1993, 247; TopÁl 1995, 104; The glazed casseroles may have been used at the ceremony performed on the $9^{\text {th }}$ day following the burial (cena novemdialis).

24 TopÁl 1993, 247; TopÁl 1995, 104. 


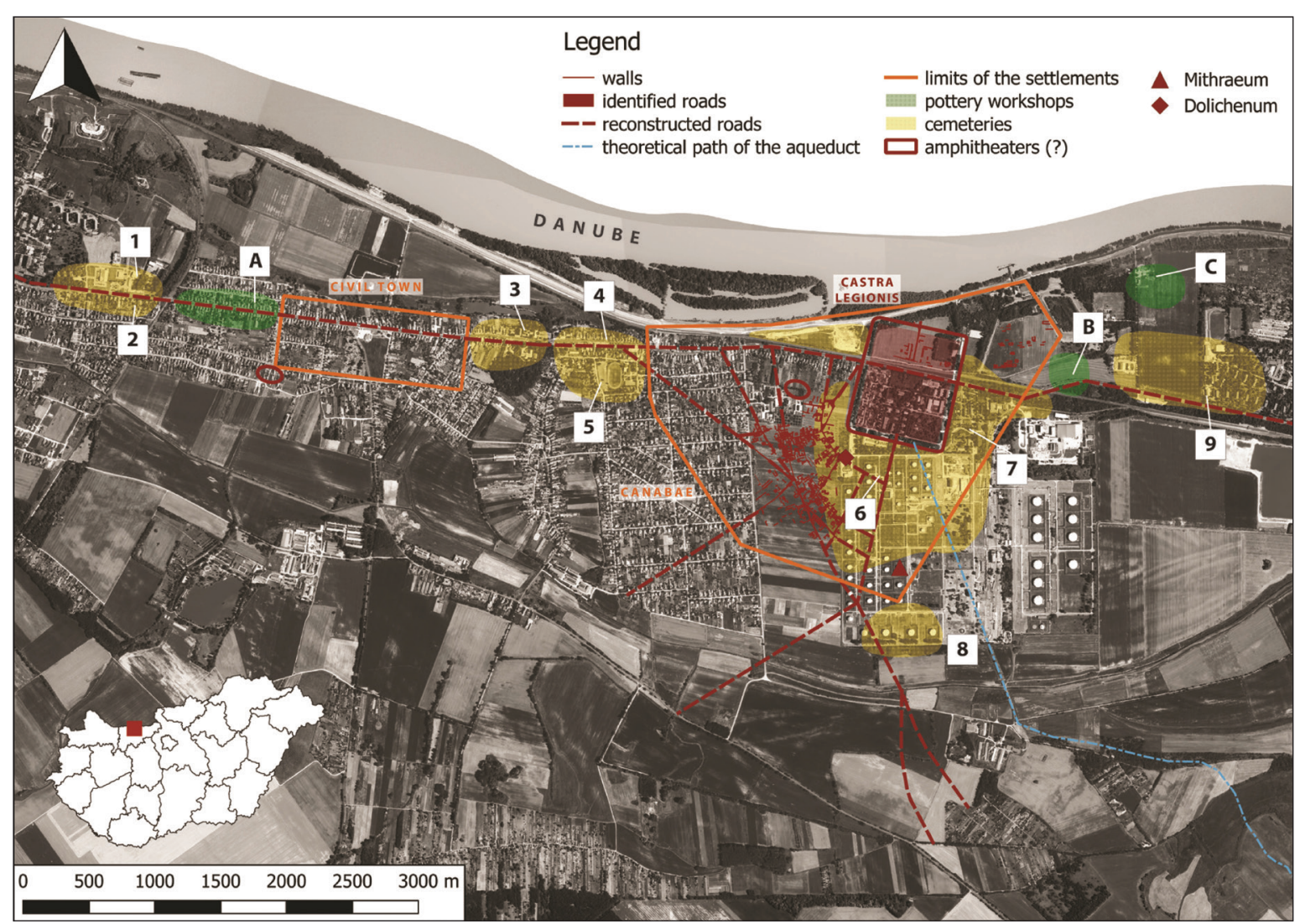

Fig. 2. Map of Brigetio (by László Rupnik). 1 - Cemetery III of municipium, 2 - cemetery II of municipium, 3 - cemetery I of municipium, 4 - Sörházkert cemetery, 5 - Járóka cemetery, 6 - Mercator cemetery, 7 - Cellás cemetery, 8 - Caecilia cemetery, 9 - Gerhát cemetery, A - Pottery workshop of municpium, B - Gerhát pottery workshop, C - pottery workshop at Kurucdomb.

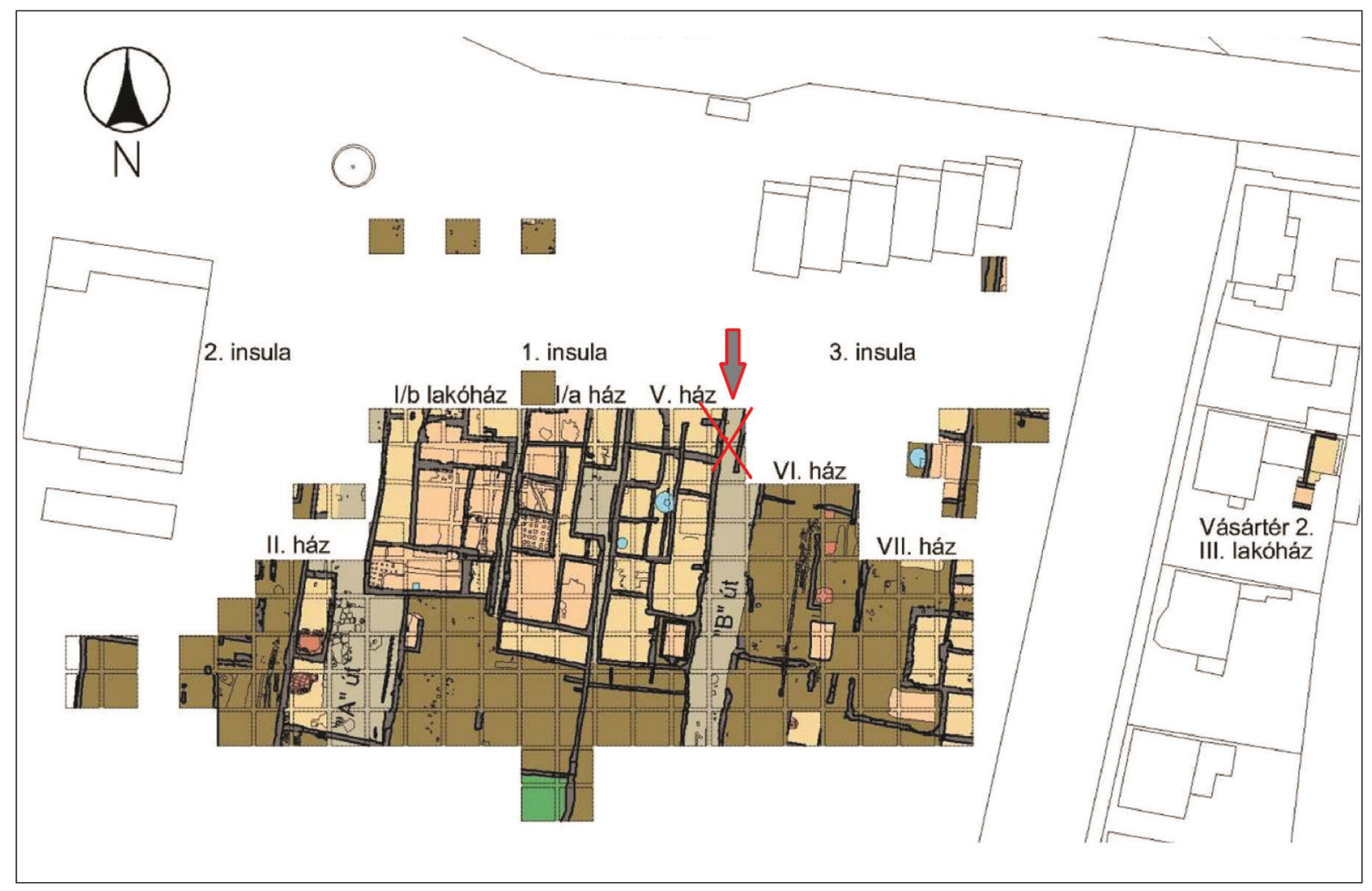

Fig. 3. Map of the municipium with the site of the mold marked (map by Linda Dobosi). 
hairstyle imitates a crescent, thus she represents the goddess Luna. ${ }^{25}$ Her appearance on the relief handles is due to her role in the Mithras cult and the importance of the astral afterlife, where the moon is the realm of the souls. In contrast, Titus Kolník identifies her as Kybele, ${ }^{26}$ Gassner as Venus, or perhaps the Gallic Dea Nutrix..$^{27}$ Adél Bugán, who connects the production and representations of the casseroles to the Egyptian cults that flourished in the second half of the $2^{\text {nd }}$ century, sees the figure as Isis. ${ }^{28}$ According to Ivana Popovič, the appearance of the type in Moesia could be related to the expansion of the Silvanus cult. ${ }^{29}$ The handles with semicircular endings depicting a woman with a double bun are prevalent in the area of Aquincum and Mursa. According to Topál, the handles have such uniform iconography that they must have been produced at a common workshop in Aquincum, even using the same or very similar molds. ${ }^{30}$ Gassner locates the manufacturing rather to Southern Pannonia, most likely to Mursa. ${ }^{31}$ Of the fragments from Brigetio nr. 1. depicting a blurred female head, does not follow the iconography of the previously mentioned handles, while nr. 2. does. Bugán argues that, as their quality is considerably inferior, they must have been produced at a different workshop. ${ }^{32}$

Topál ${ }^{33}$ has identified the nude youth depicted on the clay mold and nr. 3-4. as Amor. Furthermore, the grape motif on $\mathrm{nr}$. 4. and the clay mold are undoubtedly the symbols of Dionysus, who is connected to the idea of the eternal circle, the constant renewal of life, afterlife and rebirth. Amor signifies life after death, and the jug in his hand represents the water of life. According to Bugán, the youth is Harpocrates, the joy of Isis. ${ }^{34}$ The rosettes surrounding the figure on nr. 3. are the roses symbolizing the goddess herself. ${ }^{35}$

\section{Manufacturing technique of the clay mold}

For the analysis of the manufacturing technique of the Brigetio clay mold, we can take into account the production of the Gallic metal casserole handles and the toolkit of the potters, the study of which was already done in the 1970 s. ${ }^{36}$ According to these, it seems likely that first a model was used to outline the contours of the clay mold. Thereafter, the seals were pressed into it one by one to form the negative images of the relief decoration. Some details were etched in subsequently in a secondary manner. Regarding the fragment from Brigetio, first the central figure was imprinted, then the rosettes around it starting from the right-hand side. There should have been two on three sides, i.e., a total of six to be produced in an orderly manner, but the fifth and sixth were placed too close to each other, thus creating a smaller space on the left-hand side. This explains why another rosette was crammed into the field. Only thereafter were the grapes and the string of pearls added with the use of a pointer tool with a round end. lish the fragments from the Gázgyár in the 1930s came to similar conclusions (KuzsinszKy 1932, 351).

26 Kolník 1984, 279.

27 GASSNER 1991, 26

28 Bugán 2002, 108.

29 Popovič 2008.

30 TopÁl 1993, 246; TopÁl 1995, 102-103.

31 GASSNER 1991, 32.

32 BugÁn 2002, 98.

33 TopÁl 1993, 247; TopÁl 1995, 104.

34 Oral statements by A. Bugán.

35 Bugán 2002, 108.

36 Vertret 1972, 18-20. 

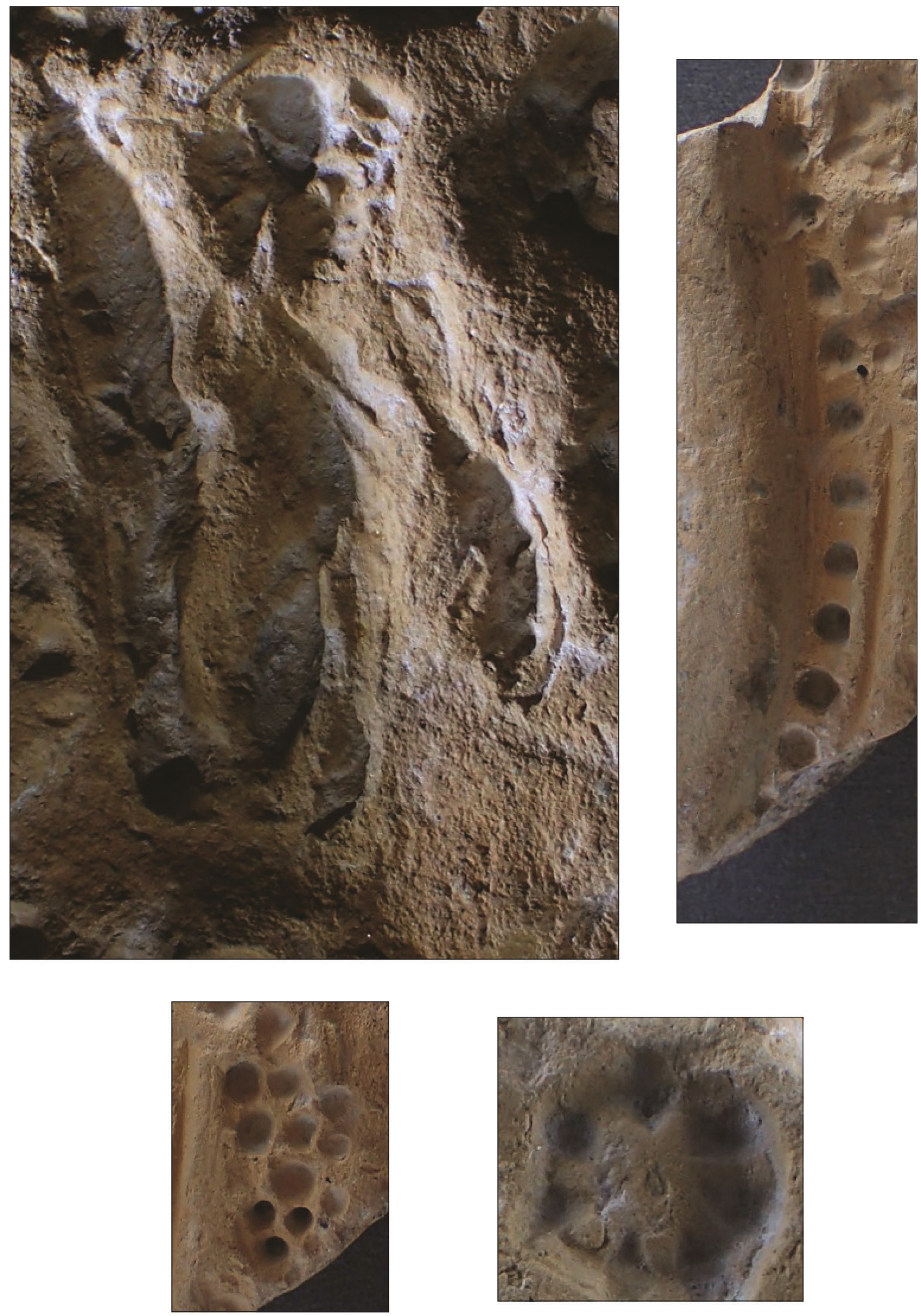

Fig. 4. Detail photos of the mold from Brigetio (Photo by Krisztina Horváth). 


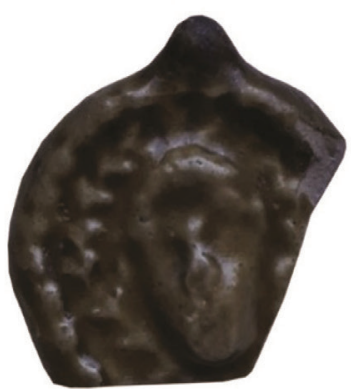

Nr. 1.

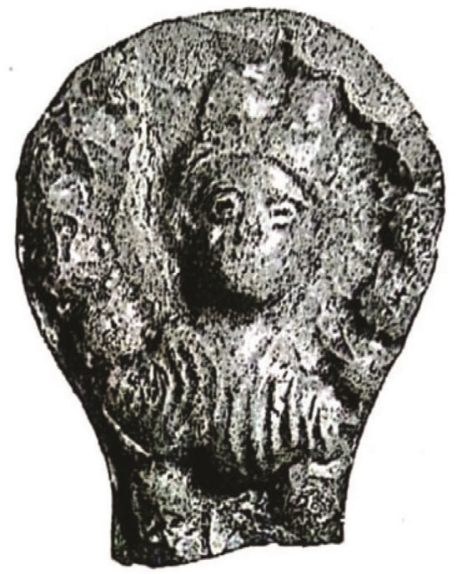

Nr. 2.

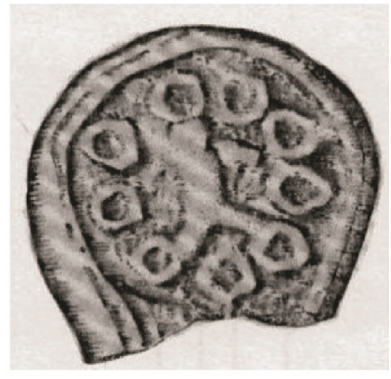

Nr. 3.

Fig. 5. Glazed casserole handles from Brigetio (Nr. 1 photo by Gabriella G. Delbó, Nr. 2 after GASSNER 1992, Abb. 4; Nr. 3 after Topál 1993, 10. kép).

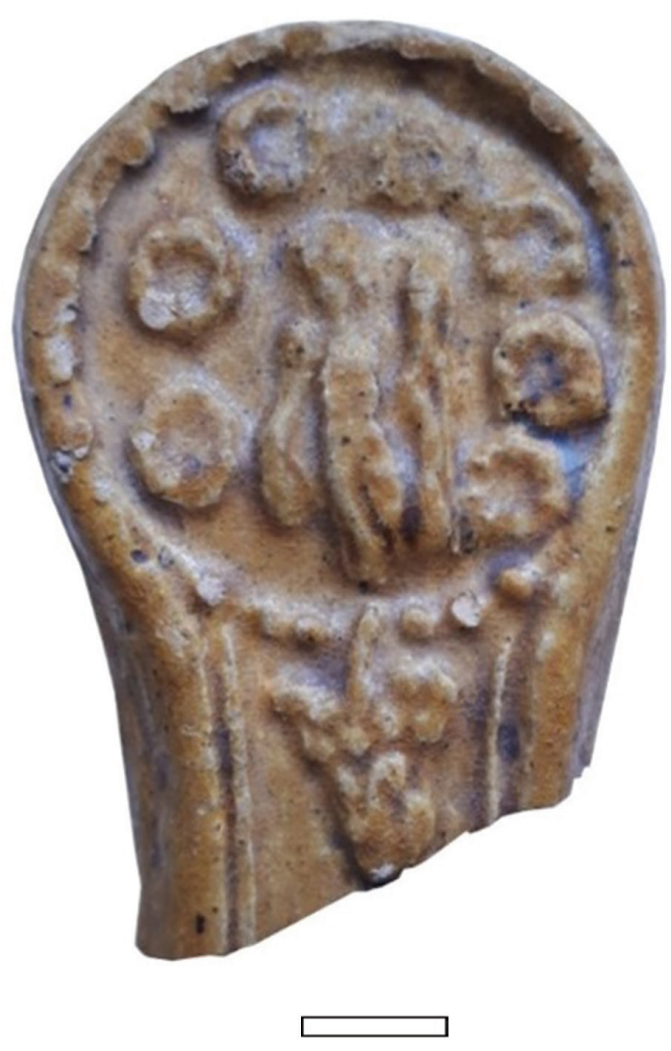

Fig. 6. Glazed casserole handle from Brigetio. Nr. 4 (Photo by Gabriella G. Delbó).
We have little information about the owner of the clay negative, who was probably the potter himself. His initials can clearly be seen on the back side, where it was impressed with a cylindrical seal ${ }^{37}$ in the leather hard clay, before firing the mold: $C \bullet M$. It is clear that he is not identical with Valerius Maximus, whose VALMAX abbreviation is found on the handle fragments at Aquincum and Mursa. ${ }^{38}$

\section{Place of production in Brigetio}

The question arises why a tool used at a pottery workshop has turned up in an alley in the middle of the civil town. The glazed pottery in Brigetio was produced at the Gerhát pottery workshop that was operational from Hadrianic times to the $230 \mathrm{~s}^{39}$ This is based on an unsuccessfully fired, deformed, light grey (2.5Y 7/2), yellow glazed (5Y 6/6) dish with a horizontally everted rim. ${ }^{40}$ Here a ram headed model ${ }^{41}$ based on Gallic antecedents and a ram headed handle from a different mold were found. ${ }^{42}$

The cylindrical seal was found at the Gázgyár pottery workshop at Aquincum; for its use, see BUGÁN 2002, 8 kép. 7.

Topál 1993, 246, Kat. 11, 11. kép; Topál 1995, 103, Nr. 11, Abb. 7.11; BugÁn 2002, Kat. 13, 1-2. kép 13.

On the production program of the pottery workshop, see: B. Bónis 1979.

B. BónIs 1979, 134, Abb. 18.10 = Abb. 23.3; BARkóczi 1992, 8-9, Abb 5.

B. Bónis 1979, 120, Abb. 11.11 = Abb. 22 4a-b.

B. BóNIs 1979, 120, Abb. 11.12 = Abb. 22.2. 


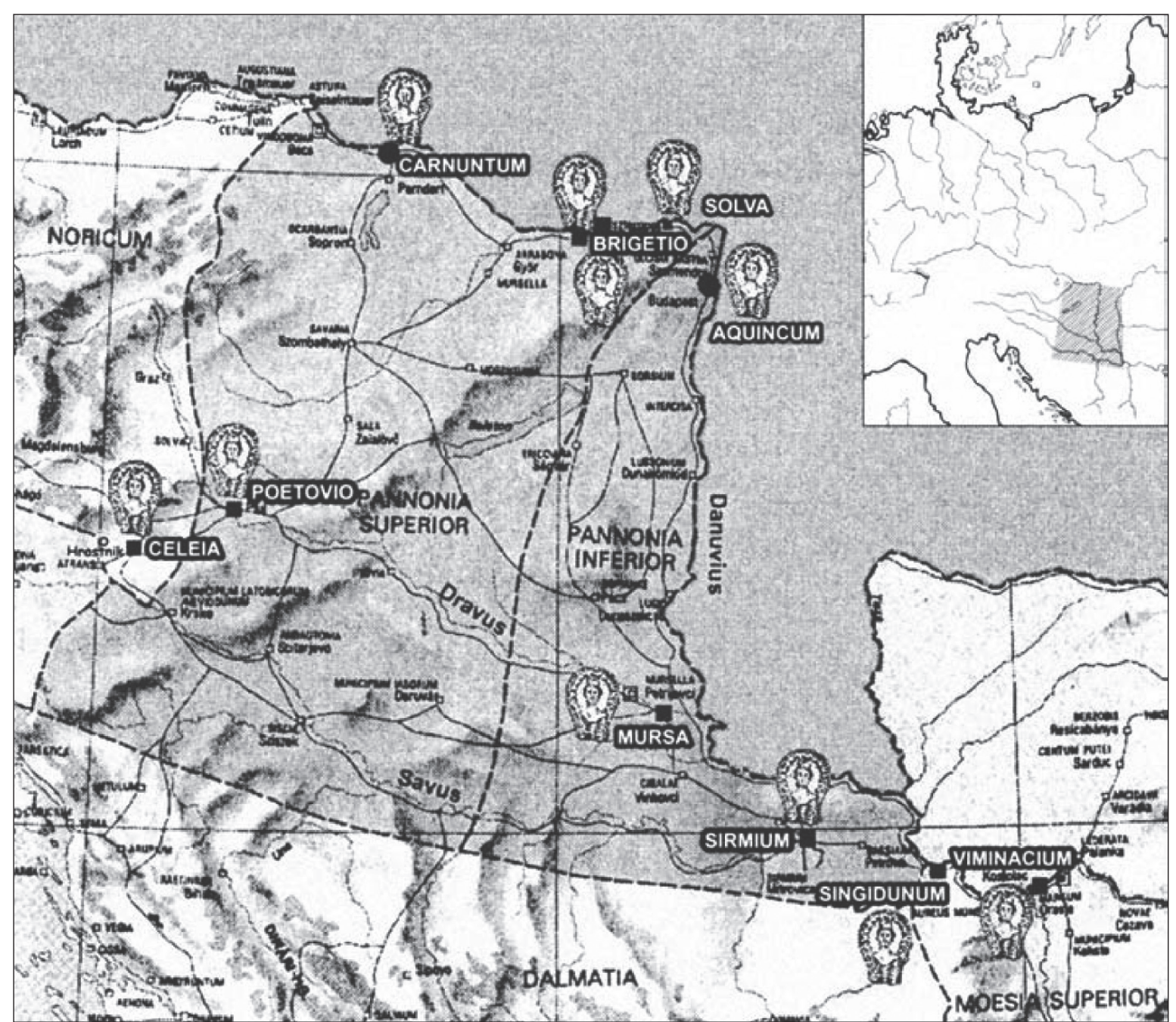

Fig. 7. Glazed casserole handles from Pannonia (after Popovič 2008, Fig. 12).

One of the key characteristics of the ceramics from Brigetio is their material of white and greyish white clay that, as Éva Bónis points out, was typical of the Gerhát pottery workshop in its early stage in the middle of the $2^{\text {nd }}$ century. ${ }^{43}$

Based on the above, the use of the clay mold and the production of the glazed handle fragments of white or greyish white material in Brigetio can be dated to the middle to the second half of the $2^{\text {nd }}$ century AD. The place of production was the Gerhát pottery workshop. It is unique and fortunate that not only the mold but also a glazed casserole handle - produced by this very mold - are available from Brigetio. The handle was buried as part of grave goods in the no. I cemetery of the municipium. The owner of the mold may have been one of the potters in the Gerhát workshop, who probably worked there only for a short time - as indicated by the small number of finds. 
Catalog of the Pannonian glazed casserole handles and mold up to 2018

\begin{tabular}{|c|c|c|c|c|}
\hline & Site & Inv. $n r$. & Museum & References \\
\hline 1 & Brigetio & K1212 & $\begin{array}{l}\text { Kuny Domokos Muzeum, } \\
\text { Tata (HU) }\end{array}$ & $\begin{array}{l}\text { BÁNKI - CSERMÉNyi 1992, 76, Kat. } \\
\text { 22, Abb. 45; TOPÁL 1993, 245, Nr. 7, } \\
\text { 7. kép; TopÁl 1995, 101-102, Nr. 7, } \\
\text { Abb. } 5.7\end{array}$ \\
\hline 2 & Brigetio & - & $\begin{array}{l}\text { Museum of Danube, Komar- } \\
\text { no (SK) }\end{array}$ & $\begin{array}{l}\text { Kolník 1984, Abb. 61; GASSNER 1991, } \\
\text { 18, BR 3, Abb } 4\end{array}$ \\
\hline 3 & Brigetio & 78.1983 .2 & $\begin{array}{l}\text { Hungarian National } \\
\text { Museum, Budapest (HU) }\end{array}$ & $\begin{array}{l}\text { B. BóNIS 1990, 6. kép 2; GASSNER } \\
\text { 1991, 16, BR 1, Abb. 4; BÁNKI - } \\
\text { CSERMÉNYi 1992, 76, Kat. 20, Abb. 44; } \\
\text { TopÁL 1993, 245-246, Kat. 10, 10. kép; } \\
\text { TopÁL 1995, 102, Nr. 10, Abb. } 7.10\end{array}$ \\
\hline 4 & Brigetio & K712/e. & $\begin{array}{l}\text { Kuny Domokos Muzeum, } \\
\text { Tata (HU) }\end{array}$ & $\begin{array}{l}\text { BÁNKi - CSERMÉnyi 1992, 76, Kat. } \\
\text { 21, Abb. 43; TopÁl 1993, 245, Nr. 9, } 9 . \\
\text { kép; TopÁl 1995, 102, Nr. 9, Abb. } 6.9\end{array}$ \\
\hline 5 & Aquincum & 30240 & $\begin{array}{l}\text { Budapest History Museum } \\
\text { (BHM) Aquincum Museum, } \\
\text { Roman Collection (RC), } \\
\text { Budapest (HU) }\end{array}$ & $\begin{array}{l}\text { KuZSINSZKY 1932, 351, 360. kép; } \\
\text { NAGy 1945, 296, 14. kép; BÁNKI - } \\
\text { CSERMÉNYI 1992, Kat. 24; GASSNER } \\
\text { 1991, 18, A3, Abb. 5; ToPÁL 1993, Kat. } \\
\text { 1, 1. kép; TopÁL 1995, Nr. 1, Abb. 1.1; } \\
\text { BugÁn 2002, Kat. 11, 1-2. kép } 11\end{array}$ \\
\hline 6 & Aquincum & 30241 & $\begin{array}{l}\text { BHM Aquincum Museum, } \\
\text { RC, Budapest (HU) }\end{array}$ & $\begin{array}{l}\text { Nagy 1945, 14. kép TopÁl 1993, Kat. } \\
\text { 2, 2. kép; TopÁl 1995, Nr. 2, Abb. 1.2; } \\
\text { BugÁN 2002, Kat. 7, 1-2. kép } 8\end{array}$ \\
\hline 7 & Aquincum & 30238 & $\begin{array}{l}\text { BHM Aquincum Museum, } \\
\text { RC, Budapest (HU) }\end{array}$ & $\begin{array}{l}\text { BÁNKI - CSERMÉNYi 1992, Kat. } 23 . \\
\text { ToPÁL 1993, Kat. 3, 3. kép; TopÁL } \\
\text { 1995, Nr. 3, Abb. 2.3; BugÁn 2002, } \\
\text { Kat. 10, 1-2. kép } 10\end{array}$ \\
\hline 8 & Aquincum & 50.576 & $\begin{array}{l}\text { BHM Aquincum Museum, } \\
\text { RC, Budapest (HU) }\end{array}$ & $\begin{array}{l}\text { BÁNKi - CSERMÉnYi 1992, Kat. 26; } \\
\text { TopÁl 1993, Kat. 4, 4. kép; TopÁL } \\
\text { 1995, Nr. 4, Abb. 3.4; BugÁn 2002, } \\
\text { Kat. 8, 1-2. kép } 7\end{array}$ \\
\hline 9 & Aquincum & 51.880 & $\begin{array}{l}\text { BHM Aquincum Museum, } \\
\text { RC, Budapest (HU) }\end{array}$ & $\begin{array}{l}\text { BÁNKI - CSERMÉNYI 1992, Kat. 27; } \\
\text { TopÁl 1993, Kat. 5, 5. kép; TopÁl } \\
\text { 1995, Nr. 5, Abb. 4.5; BugÁN 2002, } \\
\text { Kat. 9, 1-2. kép } 9\end{array}$ \\
\hline 10 & Aquincum & 63.58.4R & $\begin{array}{l}\text { Balassi Bálint Museum, Esz- } \\
\text { tergom }(\mathrm{Hu})\end{array}$ & $\begin{array}{l}\text { B. Bónis 1990, 24, 2. kép; BÁNKI - } \\
\text { CSERMÉNYi 1992, Kat. 22/a; GASSNER } \\
\text { 1991, 18, S1, Abb 4; TopÁL 1993, Kat. } \\
\text { 6, 6. kép; TopÁL 1995, Nr. 6, Abb. } 5.6\end{array}$ \\
\hline 11 & Aquincum & 89.1.44 & $\begin{array}{l}\text { BHM Aquincum Museum, } \\
\text { RC, Budapest (HU) }\end{array}$ & $\begin{array}{l}\text { BÁNKi - CSERmÉnYi 1992, kat. 28, } \\
\text { Abb. 41, TopÁl 1993, Kat. 8, 8. kép; } \\
\text { TopÁl 1995, Nr. 8, Abb. 1.6.8 }\end{array}$ \\
\hline 12 & Aquincum & 30329 & $\begin{array}{l}\text { BHM Aquincum Museum, } \\
\text { RC, Budapest (HU) }\end{array}$ & $\begin{array}{l}\text { NAGY 1945, 296-297, 15. kép; } \\
\text { GASSNER 1991, 18, A4, Abb. 5; TopÁL } \\
\text { 1993, Kat. 11, 11. kép; TopÁL 1995, } \\
\text { Nr. 11, Abb. 7.11; BUGÁN 2002, Kat. } \\
\text { 13, 1-2. kép 13 }\end{array}$ \\
\hline
\end{tabular}


Gabriella G. Delbó

\begin{tabular}{|c|c|c|c|c|}
\hline & Site & Inv. nr. & Museum & References \\
\hline 13 & Aquincum & 30255 & $\begin{array}{l}\text { BHM Aquincum Museum, } \\
\text { RC, Budapest (HU) }\end{array}$ & $\begin{array}{l}\text { NAGY 1945, 297, 16. kép; BÁNKI - } \\
\text { CSERMÉnYi 1992, Kat. 25; ToPÁL } \\
\text { 1993, Kat. 13, 13. kép; ToPÁL 1995, } \\
\text { Nr. 13, Abb. } 8.13\end{array}$ \\
\hline 14 & Aquincum & 55.42 .2 & $\begin{array}{l}\text { BHM Aquincum Museum, } \\
\text { RC, Budapest (HU) }\end{array}$ & BugÁN 2002, Kat. 1, 1-2. kép 1 \\
\hline 15 & Aquincum & 89.1 .44 & $\begin{array}{l}\text { BHM Aquincum Museum, } \\
\text { RC, Budapest (HU) }\end{array}$ & BugÁN 2002, Kat. 2, 1-2. kép 2 \\
\hline 16 & Aquincum & 57.1 .294 & $\begin{array}{l}\text { BHM Aquincum Museum, } \\
\text { RC, Budapest (HU) }\end{array}$ & $\begin{array}{l}\text { BugÁN 2002, Kat. 3, 1-2. kép 3, } 5 . \\
\text { kép } 2-3\end{array}$ \\
\hline 17 & Aquincum & 2310 & $\begin{array}{l}\text { BHM Aquincum Museum, } \\
\text { RC, Budapest (HU) }\end{array}$ & BugÁN 2002, Kat. 4, 1-2. kép 4 \\
\hline 18 & Aquincum & 69.1 .750 & $\begin{array}{l}\text { BHM Aquincum Museum, } \\
\text { RC, Budapest (HU) }\end{array}$ & BugÁN 2002, Kat. 5, 1-2. kép 5 \\
\hline 19 & Aquincum & K49 & $\begin{array}{l}\text { BHM Aquincum Museum, } \\
\text { RC, Budapest (HU) }\end{array}$ & BugÁN 2002, Kat. 6, 1-2. kép 6 \\
\hline 20 & Aquincum & $\begin{array}{l}2311 \text { Accession } \\
\text { Number (AN) }\end{array}$ & $\begin{array}{l}\text { BHM Aquincum Museum, } \\
\text { RC, Budapest (HU) }\end{array}$ & BugÁn 2002, Kat. 12, 1-2. kép 12 \\
\hline 21 & Aquincum & $2312(\mathrm{AN})$ & $\begin{array}{l}\text { BHM Aquincum Museum, } \\
\text { RC, Budapest (HU) }\end{array}$ & BugÁn 2002, Kat. 14, 1-2. kép 14 \\
\hline 22 & Aquincum & 94.1.R.31 & $\begin{array}{l}\text { BHM Aquincum Museum, } \\
\text { RC, Budapest (HU) }\end{array}$ & BugÁN 2002, Kat. 15, 5. kép 2-3 \\
\hline 23 & Aquincum & 94.1.R.28 & $\begin{array}{l}\text { BHM Aquincum Museum, } \\
\text { RC, Budapest (HU) }\end{array}$ & Bugán 2002, Kat. 16, 5. kép 2-3 \\
\hline 24 & Aquincum & 94.1.R.30 & $\begin{array}{l}\text { BHM Aquincum Museum, } \\
\text { RC, Budapest (HU) }\end{array}$ & BugÁN 2002, Kat. 17, 5. kép 2-3 \\
\hline 25 & Aquincum & 2006.5.6 & $\begin{array}{l}\text { BHM Aquincum Museum, } \\
\text { RC, Budapest (HU) }\end{array}$ & RIKKER et al. 2016, Fig. 3.3 \\
\hline 26 & Aquincum & - & $\begin{array}{l}\text { BHM Aquincum Museum, } \\
\text { RC, Budapest (HU) }\end{array}$ & LASsÁNyi - BEChtold 2006, 78, Fig. 5 \\
\hline 27 & Aquincum & - & $\begin{array}{l}\text { BHM Aquincum Museum, } \\
\text { RC, Budapest (HU) }\end{array}$ & КiRchOF 2006, 7. kép \\
\hline 28 & Aquincum & $1943 / 21$ & $\begin{array}{l}\text { Hungarian National } \\
\text { Museum, Budapest (HU) }\end{array}$ & NaGY 1945, 1-4. kép \\
\hline 29 & Arrabona & 64.2 .27 & $\begin{array}{l}\text { Rómer Flóris Museum of Art } \\
\text { and History, Győr (HU) }\end{array}$ & $\begin{array}{l}\text { Bíró 1961, 240, 5. kép 4; B. Thomas } \\
\text { 1961, 22-25, Fig. 5-6, BÁNKi - Cser- } \\
\text { MÉNyi 1992, Kat. 19; GASSNER 1991, } \\
\text { 16, Ar 1, Abb. 3; TopÁl 1993, Kat. 12, } \\
\text { 12. kép; TopÁl 1995, Nr. 12, Abb. } 7.12\end{array}$ \\
\hline 30 & Carnuntum & - & $\begin{array}{l}\text { Österreichische Akademie } \\
\text { der Vissenschaften, Wien } \\
\text { (A) }\end{array}$ & GASSNER 1991, 10, C4, Abb. 1 \\
\hline 31 & Mursa & 835 & $\begin{array}{l}\text { Archaeological Museum } \\
\text { Osijek, Osijek (CRO) }\end{array}$ & GASSNER 1991, 20, M1, Abb. 6 \\
\hline
\end{tabular}


New data on the Pannonian glazed casserole handles

\begin{tabular}{|c|c|c|c|c|}
\hline & Site & Inv. $n r$. & Museum & References \\
\hline 32 & Mursa & 836 & $\begin{array}{l}\text { Archaeological Museum } \\
\text { Osijek, Osijek (CRO) }\end{array}$ & GASSNER 1991, 20, M2, Abb. 7.10 \\
\hline 33 & Mursa & 834 & $\begin{array}{l}\text { Archaeological Museum } \\
\text { Osijek, Osijek (CRO) }\end{array}$ & GASSNER 1991, 20, M3, Abb. 7.10 \\
\hline 34 & Mursa & 7095 & $\begin{array}{l}\text { Archaeological Museum } \\
\text { Osijek, Osijek (CRO) }\end{array}$ & GASSNER 1991, 20, M4, Abb. 7.10 \\
\hline 35 & Mursa & 1346 & $\begin{array}{l}\text { Archaeological Museum } \\
\text { Osijek, Osijek (CRO) }\end{array}$ & GASSNER 1991, 20, M5, Abb. 7.10 \\
\hline 36 & Mursa & 1316 & $\begin{array}{l}\text { Archaeological Museum } \\
\text { Osijek, Osijek (CRO) }\end{array}$ & $\begin{array}{l}\text { NAGY 1945, 15. kép, GASSNER 1991, } \\
\text { 22, M6, Abb. } 7.13\end{array}$ \\
\hline 37 & Mursa & 2823 & $\begin{array}{l}\text { Archaeological Museum } \\
\text { Osijek, Osijek (CRO) }\end{array}$ & GASSNER 1991, 22, M7, Abb. 7 \\
\hline 38 & Mursa & $2823 b$ & $\begin{array}{l}\text { Archaeological Museum } \\
\text { Osijek, Osijek (CRO) }\end{array}$ & GAssner 1991, 22, M8, Abb. 7 \\
\hline 39 & Mursa & - & - & GASSNER 1991, Abb. 14 \\
\hline 40 & Poetovio & - & Museum Ptuj? (SLO) & $\begin{array}{l}\text { Mikl Curk 1965, Taf. 3.8; GASSNER } \\
\text { 1991, 24, P1, Abb. } 8\end{array}$ \\
\hline 41 & Sirmium & - & - & Popovič 2008,120 , no. 1 , Fig. 1 \\
\hline 42 & Sirmium & - & - & Popovič 2008, 121, no. 2, Fig. 2 \\
\hline 43 & Sirmium & - & - & Popovič 2008, 121, no. 3 , Fig. 3 \\
\hline 44 & Sirmium & 254 & - & Popovič 2008 , 121, no. 4, Fig. 4 \\
\hline 45 & Sirmium & - & - & Popovič 2008, 122, no. 5, Fig. 5 \\
\hline \multicolumn{5}{|c|}{ Moesia } \\
\hline 46 & Singidunuum & - & - & Popovič 2008, 123, no. 6, Fig. 6 \\
\hline 47 & Singidunuum & - & - & Popovič 2008 , 123, no. 7 , Fig. 7 \\
\hline 48 & Viminacium & - & - & Popovič 2008, 124, no. 8, Fig. 8 \\
\hline \multicolumn{5}{|c|}{ Noricum } \\
\hline 49 & $\begin{array}{l}\text { Podkraj near } \\
\text { Hrastnik } \\
\text { (Celeia) }\end{array}$ & - & - & $\begin{array}{l}\text { KRAJŠEK - STERGAR 2008, 248-249, } \\
\text { Fig. } 5\end{array}$ \\
\hline
\end{tabular}

\section{References}

BÁnki, Zs. - Cserményi, V. (eds): Glasierte Keramik in Pannonien. A Szent István Király Múzeum Közleményei D:212. Székesfehérvár.

BARKóczI, L. 1992: Frührömische glasierte Keramik in Ungarn. In: Bánki, Zs. - Cserményi, V. (eds): Glasierte Keramik in Pannonien. A Szent István Király Múzeum Közleményei D:212. Székesfehérvár, 7-35.

BíRÓ, E. 1961: Győr-Nádorvárosi koracsászárkori sírok (Frühkaiserzaitliche Gräber in Győr-Nádorváros). Archaeologiai Értesítő 88, 240-248.

B. Bónis É. 1979: Das Töpferviertel “Gerhát” von Brigetio (A brigetioi Gerhát fazekastelep). Folia Archaeologica $88,99-155$. 
B. BóNIs, É. 1990: A mázas kerámia Pannoniában. Előzmények és gyártási központok (Die glasierte Keramik in Pannonien. Entwicklungsgang und Erzeugungszentren). Archaeologiai Értesitő 117, 24-38.

BUGÁN, A. 2002: Újabb kutatási eredmények az aquincumi lelőhelyü ólommázas serpenyők gyártásának körülményeiről (Neue Forschungsergebnisse über die Produktionsumstände der bleiglasierten Pfannen aus Aquincum). Communicationes Archaeologicae Hungariae, 93-116.

Gassner, V. 1991: Mittelkaiserzeitliche glasierte Keramik aus Pannonien. Carnuntum Jahrbuch, 32-49.

KrajšEK, J. - Stergar, P. 2008: Keramika z rimskega svetiščnega območja v Podkraju pri Hrastniku (The pottery material from the Roman sanctuary area at Podkraj near Hrastnik). Arheološki Vestnik 59, 245-247.

Kirchof, A. 2006: 12. Budapest, III. ker., Beszterce utca 4-6., Hrsz.: 17544. Aquincumi Füzetek 12, 219-221.

KolNík, T. 1984: Römische und germanische Kunst in der Slowakei. Bratislava.

Kuzsinszky, B. 1932: A gázgyári római fazekastelep Aquincumban (Das grosse römische Töpferviertel in Aquincum bei Budapest). Budapest Régiségei 11. Budapest.

LAssányi, G. - Bechtold, E. 2006: Újabb feltárások az Aranyhegyi-patak menti temetőben (Recent excavations in the cemetery along the Aranyhegyi Stream). Aquincumi Füzetek 12, 73-78.

MikL CuRк, I. 1965: K sliki naselbinske keramike rimskega Poetovija (Beitrag zur Siedlungskeramik des römischen Poetovio). Časopis za zgodovino in narodopisje 1, 75-86.

NAGY, L. 1945: Zöldzománcos római dísztál Budáról. Adatok a pannóniai zománcos kerámiához (Le vase de luxe à glaçure verte de Buda). Budapest Régiségei 14, 283-299.

Nuber, H. U. 1972: Kanne und Griffschale. Ihr Gebrauch im täglichen Leben und die Beigabe in Gräbern der römischen Kaiserzeit. Bericht der römisch-germanischen Komission 53, 7-232.

Popovič, I. 2008: Relief decorated handles of ceramic patrae from Sirmium, Singidunum and Viminacium. Starinar 58, 119-134. DOI: 10.2298/STA0858119P

Rikker, B. - VÁmos, P. - Tóth, M. - MAY, Z. 2016: The archaeometric analysis of grave ceramics I. Raetian beakers and lead-glazed set from the eastern cemetery of the Aquincum civil town. Rei Creariae Romanae Fautorum Acta 44, 651-659.

Rusu-Bolindep, V. 1997: Griffe keramische paterae aus dem römischen Dakien. Acta Musei Napocensis 34, $325-388$.

TASSINARI, S. 1970: Patères à manche orné. Gallia 28, 127-163. DOI: 10.3406/galia.1970.2547

B. ThомAs, E. 1961: Római kori mázas agyag díszedények a Győri Múzeumban (Roman Glazed Ware ornamental vessels in the Győr Museum.) Arrabona 3, 17-32.

TopÁL, J. 1993: A pannonia mázas serpenyőfogókhoz (A contribution to glazed casserole handles from Pannonia). Budapest Régiségei 30, 245-261.

TopÁL, J. 1995: Glasierte Kasserollengriffe aus Pannonien. Rei Creariae Romanae Fautorum Acta 34, 101-113.

VERTRET, H. 1972: Mances de pater ornés en Céramique de Lezoux. Gallia 30, 5-40. DOI: 10.3406/galia.1972.2594

(c) 2022 The Author(s).

(c) (i) (5) This is an open-access article distributed under the terms of the Creative Commons

Attribution-Non Commercial 4.0 International Licence (CC BY-NC 4.0). 